\title{
THE USE OF IOWA COAL FOR STEAM PRODUCTION
}

\author{
T. A. Marsh. \\ Engineer, Combustion Engineering Co., Chicago
}

The coals of Iowa are among the most easily burned fuels found anywhere. This statement may sound somewhat startling, neyertheless it is a fact. Iowa coals give less difficulties than the anthracites or some of the eastern coking coals.

I do not wish to give the impression that few difficulties have been encountered in the past with Iowa coal. Quite the contrary. However, when in the light of to-day's knowledge we take a retrospect of the past 25 years' practice, experiments and development in the art of burning Iowa coals, we can find little or no logic or engineering reason for much of the work.

Most of the early designs of grates and furnaces were as evidently in error as would be a bridge not strong enough to carry the load of a train or a cylinder not strong enough to resist steam pressure without bursting.

The many faulty engineering designs and failures to properly burn the coals of Iowa were due largely to the following causes: lack of thorough information regarding the fuel characteristics; lack of knowledge in the art of combustion; the fact that in many instances if Iowa coal gave difficulties, Illinois or other coal could be substituted.

To-day, with the elements of the problem well understood and with many plants burning Iowa coal with marked sucess and high efficiency, it is interesting to look back and note the various steps leading to the development of present day successes.

The coals of Iowa are now well known chemically. Their physical and combustion characteristics are well established. In general, Iowa coals classify as free burning bituminous coals of high ash content. The ash fuses at a temperature usually below $2200^{\circ} \mathrm{F}$.

The high ash content of the coal makes it difficult to ignite and rather slow to burn in fuel beds. The low fusion temperature of the ash renders the coal very susceptible to clinker formation at ordinary furnace temperatures. Clinker formation on grates retards combustion and therefore further reduces the amount of coal that can be burned.

The above general remarks state broadly the problems to be met in the burning of Iowa coals. During the last twenty years prac- 
tically all known types of stokers have been tried with Iowa coal. The earlier installations at the beginning of this century were largely of the inclined overfeed type of stoker. With this type of stoker the fuel bed was agitated, and the ash from the lower part of the fuel bed was frequently brought up to the hotter zone near the top of the fuel bed. The temperature near the top of the fuel bed being above that of the fusion temperature of the ash, fusion resulted and clinker was formed.

These early types of stokers were provided with clinker dumping devices. The high percentage of ash found in Iowa coal naturally increased considerably the amount of ash and clinker to be removed from the furnace and made the performance of stokers using dumping plates quite limited.

It was very evident that such fuel bed action could not be at all successful with Iowa coal. The formation of clinker in large quantity clogged the grate and disrupted the fuel bed. Combustion rates were low, ash pit losses were high, operation was most difficult and maintenance excessive.

At about the same time, a number of early designs of underfeed stokers were installed throughout Iowa. These stokers used forced blast and built up high temperatures in and just above the fuel bed. The limitation of this type of stoker was again due to the formation of clinker, and while good combustion rates were obtained for short periods clinkers formed so rapidly and were removed with such difficulty that the operation was very strenuous and the service of the stokers short-lived.

A thorough knowledge of the fuel and its characteristics would no doubt have saved expense and prevented numerous failures of stokers of these types for burning Iowa coal.

Following the era of overfeed and underfeed stokers in Iowa came what might be termed the chain grate period. From the general analysis of average Iowa coal, it was evident this type of stoker was basically more suitable than either the overfeeds or underfeeds as clinkers were avoided.

The reasons for this were, first the ash was continuously scavenged from the furnace leaving no deposit for clinker formation and the subsequent periodic dumping was eliminated. Second, the fuel bed was undisturbed, and the ash remained where it was formed, at the bottom or cooler side of the fuel bed.

Even with these characteristics in their favor, most of the early 
chain grate installations were very limited in performance. Difficulty was experienced in igniting the fuel at proper rates, owing to lack of knowledge of furnace design and arch length and location.

Most early installations were quite limited in the item of rating. This was attributable to two causes in so far as stoker and furnace were concerned, namely improper furnace design and insufficient grate area.

Among the successful early installations were the Des Moines City Railway Company's installation, installed about 1913, at which plant work was done on Iowa coals. The work of the Iowa Railway and Light Company has been a most valuable addition to the knowledge of the burning of Iowa coal with chain grates.

About six years ago the forced draft chain grate was successfully applied to bituminous coals. This factor added much to the performance obtainable with Iowa coals. Some of the poorer grades of Iowa coal are so inert that under natural draft conditions combustion rates are too low to maintain bigh furnace temperatures. This in turn reacts on the ability to ignite more coal. The use of forced draft in various zones or compartments in stokers furnishes a means of regulating the air supply which improves ignition and greatly increases the combustion rates obtainable.

One of the first in the state to make an installation of forced draft chain grates was the Fort Dodge, Des Moines \& Southern Ry., at their Frazer plant. The local coal is very high in ash, frequently above 25 per cent. The calorific value is frequently below 7500 B.t.u. With natural draft chain grates they found it difficult to ignite and burn enough fuel for their required ratings. Forced draft with increased combustion rates, higher furnace temperatures, higher capacities and much less sensitive operation produced the required results.

One of the most recent installations in Iowa, the Des Moines Station of the Iowa Power \& Light Company, is equipped with this stoker type and is giving excellent results with Iowa coal.

While the development of the natural and forced draft traveling grate was progressing, the multiple retort underfeed stoker was going through a similar development. An early installation of this type of stoker was made at the Cedar Rapids plant of the Iowa Railway \& Light Company. Similar to other stoker types that had entered this field, the grate surfaces were not made so liberal as is now known to be desirable. This type of stoker agitates the fuel 
bed and clinker formation results. The higher the combustion rate the more serious the clinker problem becomes. Much improved results have more recently been obtained by stokers of this type, but they are considerably more liberal in grate area than the early types. This stoker type has been installed at the Riverside plant of the United Light \& Power Company near Davenport, which is one of the more recent power plants of the state.

Iowa coal burns best when reduced to a size all of which will pass through a 1 in. round hole screen. The tempering or moistening of Iowa coal is very important, and the better combustion engineers of the state have learned much in this regard. Three to five per cent moisture added at least two hours before burning improves results in regard to combustion rates, $\mathrm{CO}_{2}$ and carbon in the ash. From operating reports this is said to be the case with all types of stokers.

The past five years have seen the adoption of pulverized fuel by large central stations and major industrials. Naturally when the larger new Iowa plants were being designed, decision had to be made between stokers and pulverized fuel.

At the time that the Big Sioux station of the Sioux City Gas \& Electric Company was contemplated, that company was thoroughly familiar with overfeed stokers, underfeeds and chain grates, having used all types in their various Sioux City stations. However, no tests had been made on Iowa coal in pulverized form. The possibility of the slagging of furnace walls and floor was a question, as were also the power requirements for pulverizing.

Accordingly the Sioux City Gas \& Electric Company sent several carloads of their coal to the Lakeside plant of the Milwaukee Electric Railway Light \& Power Company for tests in actual operation. The findings of these tests resulted in a decision for pulverized coal for the Big Sioux Station.

It was recognized that with the low fusion temperature of the ash, ample cooling elements should be installed in the furnace to reduce the temperature of the walls and hearth to a point below that of the melting point of the ash. This was done by means of water screens.

The Iowa Railway \& Light Company have recently installed in their Cedar Rapids plant two unit systems of pulverized coal with completely water cooled furnaces.

The excellent results possible from Iowa coal in pulverized form 
lead to the conclusion, as with most other fuels, that the finer the degree of preparation of the fuel the better the combustion results.

It is evident that the ideal method of burning Iowa coal is in pulverized form. Whether or not this can be justified in any plant under consideration becomes a problem of first costs involving investment charges, preparation charges, in fact all items involved in the final and total cost per thousand pounds of steam.

During the last three years air preheaters have figured strongly in the equipment of modern power stations. Air preheaters utilize the heat in the escaping flue gases to raise the temperature of the air used for combustion. Sometimes temperatures of combustion air are raised to as high as $350^{\circ}$ or $400^{\circ}$. The air so preheated helps the coal to ignite, raises the furnace temperature and so improves combustion that not only is there the gain due to the heat returned to the furnace, but there is the additional gain in capacity, improvement in ash and reduction in combustion losses. The use of preheated air for combustion is very desirable with Iowa coal.

As combustion rates and furnace temperatures have been increased with the use of low fusible ash coals it is evident that something other than refractory walls are necessary for certain parts of furnaces.

In part then, for furnace protection and the utilization of radiant energy from the fuel, has come a development of radiant water walls and radiant steam walls which play a most important part in the modern installation. Elements exposed to radiant heat operate at very high absorption rates. With the use of forced draft stokers and pulverized coal at high ratings, radiant walls are most desirable. Where highly preheated air is used radiant water or steam walls become more necessary to reduce fumace maintenance.

To summarize the situation as it stands to-day, in major plants burning Iowa coal we have, therefore, pulverized fuel, natural and forced draft chain grates, multiple retort underfeeds, air preheaters, water walls. Air preheaters and water walls lend themselves better to the pulverized fuel furnace than to the stoker furnace. Larger areas can be covered with radiant water walls or radiant superheaters in pulverized fuel furnaces than in stoker furnaces.

As the problem now stands the ideal furnace of to-day for burning Iowa coal would be the pulverized fuel furnace with radiant water walls or radiant steam walls or both, in combination, and the 
use of highly preheated air under definite regulation in connection with definite regulation of fuel.

In cases where the economics of the problem indicates stokers, the most desirable type of stoker is the forced draft traveling grate with preheated air and water walls. For those installations not requiring the higher capacity obtainable with pulverized fuel or with forced draft, the natural draft chain grate is suitable. Such installations should be made with liberal arches, at least 60 per cent of the stoker length and set high above the fuel bed. Stokers for Iowa coals should have liberal grate area and should preferably be $12 \mathrm{ft}$. long or longer.

We have, therefore, very suitable and highly efficient methods of burning Iowa coal. Such methods and such state of the art have required years of development.

Now that the methods are known, the burning of Iowa coal is indeed easier than the burning of many other supposedly superior coals from other localities.

As a supplement to this paper the author appends drawings showing the general furnace designs and some combustion results of the Big Sioux Station, Sioux City Gas \& Electric Co.; the Des Moines Station, Iowa Power \& Light Co.; the Cedar Rapids Station, Iowa Railway \& Light Co.; the Des Moines City Railway, Des Moines, Iowa; State University of Iowa, Iowa City. (Not printed.)

The United Light \& Power Company reports that they do not burn Iowa coal in their Riverside plant. To date only 4 or 5 cars have been used. They submit however, some Iowa coal tests made at the Moline, Rock Island Manufacturing Company's plant with Iowa coal.

IOWA COAL TESTS AT MOLINE ROCK ISLAND MANUFACTURTNG CO.

Type of stoker-Multiple retort underfeed

Kind of coal-2-in. screenings from Tracy, Iowa

Per cent moisture

$\begin{array}{lllll}\text { Per cent volatile } & 30.23 & 27.57 & 26.30 & 29.46\end{array}$

$\begin{array}{lllll}\text { Per cent fixed carbon } & 33.67 & 35.15 & 35.21 & \mathbf{3 5 . 3 2}\end{array}$

$\begin{array}{lllll}\text { Per cent ash } & 18.28 & 17.25 & 18.08 & 17.14\end{array}$

$\begin{array}{lllll}\text { B. t. u. per pound of coal as fired } & 8461 & 8021 & 8113 & 8445\end{array}$

$\begin{array}{llllll}\text { Pounds of coal per sq.ft. of grate per hr. } & 24.2 & 31.5 & 37.7 & \mathbf{4 8 . 6}\end{array}$

$\begin{array}{lllll}\mathrm{CO}_{2} \text { in flue gases-per cent } & 10.82 & 12.13 & 11.01 & 10.65\end{array}$

$\begin{array}{lllll}\text { Combustible in ash-per cent } & 9.30 & 13.40 & 22.51 & 43.59\end{array}$ 
Type of stoker-Natural draft chain grates Kind of coal-2-in. screenings from Tracy, Iowa Per cent moisture Per cent volatile $\quad 31.27$ Per cent fixed carbon $\quad 33.75$ Per cent ash $\quad 18.28$ B. t. u. per pound of coal as fired 8572 Pounds of coal per sq.ft. of grate per hr. $\quad 27.1$ $\mathrm{CO}_{2}$ in flue gases-per cent 13.13 Combustible in ash-per cent

$\begin{array}{ccc}18.96 & 15.14 & 18.17 \\ 30.71 & 32.19 & 30.32 \\ 33.65 & 36.21 & 35.23 \\ 16.68 & 16.46 & 16.28 \\ 8468 & 9402 & 8760 \\ 30.2 & 32.6 & 37.4 \\ 12.42 & 11.95 & 13.18 \\ 32.87 & 35.28 & 41.60\end{array}$

IOWA COAL RESULTS FROM SIOUX CITY GAS \& ELECTRIC CO. BIG SIOUX STATION, WITH PULVERIZED COAL FIRING

The Big Sioux Station of the Sioux City Gas \& Electric Company is equipped with the bin and feeder system of pulverized coal. They report that during the months of December, 1926, and January, 1927, they pulverized and burned coal from eight different states, namely, Iowa, Illinois, Kentucky (western), Oklahoma, Arkansas, Colorado, Indiana and Missouri, and from fifteen districts within these states. No trouble was experienced in maintaining high ratings whenever required with any of these coals.

The average boiler rating for the two months was 198 per cent. The maximum was 300 per cent. The average $\mathrm{CO}_{2}$ was 13 per cent, and the boiler effciency for the two months was 83.3 per cent. They report no difficulty in operating with Iowa coal at ratings of 350 per cent and more and very little diffculties with slag.

During the month of April, 1926, the major portion of the coal used was from Waukee, Iowa. This month gave the best month's efficiency in the station history. In February, 1927, practically all Iuwa coal was burned. The average analysis was 9100 B.t.u. with 18 per cent ash. The monthly boiler efficiency was 84.5 per cent.

The high efficiencies of Iowa coals in this station have caused some thought to be given as to the reason. A theory has been advanced that the surfaces of the ash in suspension accelerate the burning of fuel by increasing the radiant energy and create an accelerating effect on combustion. This is in accord with tests made at the mines de Blanzy, France, in which it was proven that ash particles in suspension have a beneficial effect on combustion when pulverized fuel is burned by short flame travel.

The results with Iowa coal at the Big Sioux Station certainly establish the fact that lowa coals burn excellently in pulverized form and indicate that lowa coals even have advantage over many other coals in this regard.

DES MOINES CITY RAILWAY ANNUAL STATION BOILER PERFORMANCE RECORDS

\begin{tabular}{lrrrrr} 
Year & 1922 & 1923 & \multicolumn{1}{c}{1924} & \multicolumn{1}{c}{1925} & \multicolumn{1}{c}{1926} \\
B.H.P. banked & $8,203,020$ & $10,073,980$ & $10,266,301$ & $10,074,000$ & $9,880,860$ \\
B.H.P. service & $9,193,360$ & $10,419,190$ & $10,257,700$ & $9,501,700$ & $10,073,820$ \\
B.H.P. developed & $17,650,748$ & $19,365,159$ & $18,819,379$ & $17,564,826$ & $17,954,963$ \\
\% Banked to service & 89.23 & 96.70 & 100.08 & 106.03 & 98.11 \\
\% Service to gen. & 35.59 & 36.37 & 35.98 & 35.04 & 37.49 \\
\% Dev. to service & 191.99 & 185.88 & 183.45 & 184.89 & 178.28 \\
Water evaporated & & & & & \\
1000 lb. & $\mathbf{5 8 0 , 8 7 7 . 0 0}$ & $\mathbf{6 3 9 , 7 2 2 . 0 0}$ & $621,391.10$ & $580,497.00$ & $594,837.00$
\end{tabular}


Coal burned $1000 \mathrm{lb}, \quad 88,228.10 \quad 105,967.30 \quad 102,722.95$

Water evap.

per lb. coal

$\%$ Moisture as fired

6.42
14.62
18.70
9152.68
1426

6.04

15.43

21.24

6.05

$93,516.70$

$96,967.00$

$\%$ Ash as fired

B.t.u. as fired

8593.63

15.72

19.41

6.21

6.13

B.t.u. per lb.

1423

8905.63

17.05

9290.56

15.90

19.05

water evap.

71.02

$71.02 \quad 71.13$

1472

1497

8933.90

furiency of boilers,
funaces and grates

68.99

67.88

1456

The great number of these tests and the length of time covered by test periods give unusual reliance to these results.

In this station the yearly operating records also give an excellent check of test results. This station is remarkable for the keeping of unusually careful records of performance and the close relationship between test and operating results. This company is to be given much credit for results obtained.

\section{ILLINOIS POWER AND LIGHT CORPORATION}

The Illinois Power and Light Corporation has two plants in Des Moines. The old station has natural draft chain grates, no economizers and no air heaters. The new station has forced draft chain grates, economizers and air heaters on some of the units. Comparative months operating results are given on page 91 . 
IOWA COAL PERFORMANCE ON NATURAL DRAFT CHAIN GRATES

AT THE DES MOINES CITY RAILWAY COMPANY

DES MOINES, IOWA

No. of tests
Duration of tests hours
Kind coal used
Water evap. per lb. coal
Lbs. coal burned per sq.ft. grate area per hr.
\% Rating developed
Efficiency of boiler furnace and grate
Analysis of coal as fired
$\%$ Moisture
$\%$ Ash
$\%$ Sulphur
B.t.u. per lb. as fired

$\begin{array}{rrrrr}5 & 34 & 6 & 12 & 7 \\ 1071 / 2 & 713 \% / 4 & 152 \% / 4 & 289 y_{4} & 1621 / 4 \\ \text { Iowa } & \text { Iowa } & \text { Iowa } & \text { Iowa } & \text { Iowa } \\ 5.90 & 6.34 & 6.47 & 6.22 & 6.52 \\ 38.17 & 37.95 & 36.56 & 35.08 & 38.21 \\ 168.07 & 185.02 & 176.28 & 162.30 & 185.76 \\ 73.83 & 70.35 & 72.92 & 74.91 & 73.10 \\ & & & & \\ 16.33 & 14.82 & 16.51 & 16.31 & 16.99 \\ 23.10 & 16.97 & 17.96 & 21.16 & 16.63 \\ 4.20 & 4.87 & 5.23 & 5.15 & 4.11 \\ 8144.00 & 9495.02 & 9034.00 & 8435.00 & 9082.00\end{array}$

$8144.00 \quad 9495.02$

$\begin{array}{rr}5.23 & 5.15 \\ 9034.00 & 8435.00\end{array}$

082.00

\begin{tabular}{rrr} 
& & \\
& & \multicolumn{1}{l}{} \\
& & \\
& & \\
9 & 1 & \multicolumn{1}{c}{1} \\
$1871 / 4$ & 21 1 14 & $193 / 4$ \\
Iowa & Iowa & Iowa \\
5.93 & 6.68 & 6.63 \\
38.13 & 43.49 & 43.14 \\
168.73 & 216.46 & 213.41 \\
71.39 & 70.83 & 72.52 \\
& & \\
16.64 & 13.31 & 15.53 \\
22.18 & 16.09 & 17.39 \\
4.38 & 5.20 & 6.24 \\
8478.00 & 9595.81 & 9316.62
\end{tabular}




\section{DES MOINES POWER STATION OPERATING COMPARISON}

Month

Name of fuel

Tons fuel burned

Average B.T.U. as fired

Average boiler efficiency

Average rating

Average combustible in ash

Average $\mathrm{CO}_{2}$

Average uptake temp.

Steam pressure-gage

Superheat-average

Type of stoker

Air preheaters.

Superheaters

Econcmizers

Furnace side walls

Fuel At old station: from Pershing Coal Co., 9048 tons from Pershing Mine, and
from Norwood White Coal Co., 4000 tons from No. 7 Moran Mine.

At new station: from Pershing Coal Co., Pershing and Tracy Mines, and from Norwood White No. 7 and No. 8 mines, Moran and Herrold, Iowa, respectively.

Quantities from different mines not known.

Boilers in Service

At old station, all boilers with exception of two in service.

At new station, all boilers in service much of month due to regulating superheat on new boilers No. 2 and No. 4. This lowered average $\mathrm{CO}_{2}$ due to high banking H.P. hours.

New station average boiler rating is brought down due to above noted boilers in service, also due to low night loads which results in high banking H.P. hours.

The comparative results of these stations is of interest. The higher efficiency of the new station during this comparative period is due mostly to better heat absorption of boilers and economizers and air heaters. The load conditions, however, are unfortunate and the $\mathrm{CO}_{2}$ and rating results do not represent the results obtainable from forced draft chain grates under more suitable load conditions and without such a large proportion of banked boiler hours.

\section{POSSIBLE RESEARCHES IN IOWA COAL}

\section{B. P. Fleming}

Professor of Mechanical Engineering, University of Iowa

Among the many sources of wealth with which Nature has blessed Iowa are its coal measures. Dr. Lees has discussed the extent and characteristics of these deposits, and Mr. Marsh has shown what may be done to utilize this coal effectively in processes of combustion.

Iowa coal suffers from an inferiority complex due to the fact that its disagreeable and its poor qualities have been more persistently and widely broadeast than its good qualities. It also suffers from 